\title{
PELATIHAN PENGOLAHAN PRODUK BAKERI BERBASIS TEPUNG UMBI LOKAL DI PONDOK PESANTREN SULTAN FATAH SEMARANG
}

\author{
Arief R. Affandi ${ }^{1)}$, M.Khoiron Ferdiansyah ${ }^{1)}$, Nur Aksin ${ }^{1)}$ \\ Fakultas Teknik dan Informatika, Universitas PGRI Semarang \\ Email: arieftmin@gmail.com
}

\begin{abstract}
ABSTRAK
Pengolahan bahan pangan lokal merupakan salah satu strategi dalam menciptakan kestabilan kondisi ketahanan pangan di negara Indonesia ini. Permasalahan yang dihadapi adalah rendahnya minat masyarakat untuk mengolah bahan pangan lokal ini menjadi beberapa produk yang bermutu tinggi. Pemanfaatan bahan pangan lokal, seperti umbi-umbian dan jenis serealia nonberas dapat mengurangi tingkat ketergantungan masyarakat terhadap bahan baku terigu yang notabenenya termasuk barang nonlokal (impor). Kegiatan pengabdian bertujuan untuk sosialisasi program diversifikasi pangan ini kepada para pengelola dan anak asuh Pondok Pesantren Sultan Fatah yang berlokasi di Kelurahan Wonosari Kecamatan Ngaliyan Kota Semarang melalui pengolahan produk bakeri berbahan dasar tepung umbi lokal. Luaran yang dihasilkan dari pengabdian ini antara lain modul kewirausahaan, produk rerotian dari tepung lokal, pengenalan beberapa aspek yang terkait dengan pemasaran produk, dan pemahaman mengenai kualitas gizi produk yang dihasilkan. Kegiatan ini dilakukan melalui tahapan sosialisasi, pelatihan pengolahan tepung bahan lokal menjadi produk roti. Hasil pelaksanaan kegiatan menunjukkan bahwa peserta telah memiliki kemampuan mengenai proses pembuatan roti. Penggunaan bahan baku tepung umbi lokal dalam formula pembuatan produk roti memang belum menghasilkan karakteristik yang sama persis dengan produk yang dibuat dari tepung terigu.
\end{abstract}

Kata kunci : Bakeri, Tepung Umbi Lokal, Pondok Pesantren Sultan Fatah Semarang

\section{ABSTRACT}

The processing of local food ingredients is one of the strategies in creating a stable condition of food security in Indonesia. The problem faced is the low interest of the community to process these local food ingredients into several high quality products. Utilization of local foodstuffs, such as tubers and non-rice cereals, can reduce the level of community dependence on wheat flour which is not included in non-local (imported) goods. Devotion activities aim to socialize this food diversification program to managers and foster children of Sultan Fatah Islamic Boarding School located in Wonosari Village, Ngaliyan District, Semarang by processing bakery products made from local tuber flour. Outcomes generated from this service include entrepreneurship modules, local products from local flour, introduction to several aspects related to product marketing, and understanding of the nutritional quality of the products produced. This activity was carried out through the stages of socialization, training in processing local flour ingredients into bread products. The results of the implementation of the activity indicate that the participant has the ability to process the bread. The use of local tuber ingredients in the formula for making bread products does not produce the exact same characteristics of products made from wheat flour.

Keywords: Bakery, Local Tuber Flour, Boarding School Sultan Fatah Semarang 


\section{PENDAHULUAN}

Pondok Pesantren Sultan Fatah merupakan salah satu lembaga sosial masyarakat yang mengelola santri yang tergolong tidak mampu (fakir miskin) baik untuk putra dan putri yang berada di wilayah Kecamatan Ngaliyan Kota Semarang. Pada tahun 2017, panti asuhan ini mengelola 80 anak santri, terdiri dari 41 putra dan 39 putri, yang tinggal dan menetap suatu komplek bangunan. Pondok pesantren ini dikelola oleh sebuah yayasan bernama Yayasan Sultan Fatah. Yayasan ini memiliki tujuan mengangkat harkat dan martabat generasi yang lemah menjadi generasi yang bermartabat dan beradab. Kegiatan yang dilakukan dalam Panti Asuhan ini meliputi pendidikan formal dan non formal. Kegiatan pendidikan formal sudah berjalan dengan baik, begitu pula dengan pendidikan non formal, seperti pemahaman ilmu keagamaan, hafalan Al-Quran dan hadits, juga sudah berjalan dengan sangat baik. Namun, pendidikan non formal yang menyangkut keterampilan yang berkaitan dengan kewirausahaan dirasakan masih sangat kurang. Berdasarkan informasi yang diberikan oleh pihak pengelola panti asuhan, sebagian besar anak asuh yang terdaftar di panti ini masih berusia remaja. Beberapa di antaranya berasal dari keluarga yang kurang mampu. Hasil survei lapang Tim PKM didapatkan informasi bahwa sebagian besar anak-anak tersebut tidak berminat meneruskan pendidikan ke jenjang perguruan tinggi. Mereka lebih tertarik mencari pekerjaan atau membuat usaha.

Beberapa program kegiatan dengan sasaran melatih keterampilan anak didik panti asuhan ini sudah dilaksanakan di lokasi tersebut namun belum banyak program yang menyentuh aspek pengolahan bahan pangan lokal (singkong, jagung, umbi jalar) menjadi produk rerotian (bakery) yang memiliki nilai jual lebih tinggi dari bahan mentahnya. Hal ini dikarenakan adanya hambatan terkait keterbatasan peralatan pengolahan dan pengetahuan mengenai cara pengolahan bahan yang tepat. Sementara itu jika dilihat dari lokasinya, Kecamatan Ngaliyan Kota Semarang ini memiliki potensi pengembangan bahan pangan lokal yang cukup besar karena daerah di sekitar pondok pesantren banyak ditemukan kebun yang ditanami dengan berbagai jenis umbi-umbian lokal.

\section{METODE PELAKSANAAN KEGIATAN}

Tahap awal adalah tim pengabdian menyusun perencanaan pelaksanaan pelatihan meliputi penentuan jadwal pertemuan, tempat sosialisasi, agenda sosialisasi, pemateri, dan kepanitiaan. Dalam penyusunan perencanaan ini tim pengabdian melakukan kerjasama dengan para pengelola Pondok Pesantren Sultan Fatah yang berlokasi di Kelurahan Wonosari Kecamatan Ngaliyan Kota Semarang. Proses Perijinan dilakukan kepada pihak-pihak yang berkaitan dengan masyarakat yang akan diberikan pelatihan 
mengenai sosialisasi dan pelatihan produk bakeri berbasis tepung umbi.

Pengumpulan informasi mengenai permasalahan yang dialami oleh mitra dilakukan dengan melakukan diskusi singkat. Tim pelaksana pengabdian masyarakat mendatangi mitra dan mencoba menganalisis permasalahan yang dihadapi dan mencoba menawarkan solusi melalui suatu program, yang kemudian tertuang dalam program pengabdian masyarakat ini. Berdasarkan hasil wawancara tim pelaksana dengan pihak pengelola Pondok pesantren Sultan Fatah Kota Semarang maka ditentukan prioritas permasalahan yang perlu diselesaikan melalui program pengabdian masyarakat ini. Penentuan permasalahan yang muncul terkait dengan cara pengolahan roti dari tepung umbi lokal dan beberapa hal yang terkait dengan kewirausahaan, maka tim pelaksana melakukan koordinasi dengan mitra

\section{HASIL DAN PEMBAHASAN}

Beberapa kegiatan telah dilaksanakan sesuai dengan jadwal yang telah disusun pada rencana kegiatan. Selain itu, juga telah dilakukan beberapa kali pertemuan untuk koordinasi kegiatan lainnya, seperti persiapan kegiatan, akomodasi peserta pelatihan, dan sosialisasi pengurusan PIRT. Semua kegiatan yang telah dilaksanakan diharapkan mampu meningkatkan semangat para mitra untuk lebih banyak memanfaatkan bahan pangan lokal untuk diolah menjadi beberapa produk olahan pangan, khususnya roti-rotian, yang memiliki nilai jual cukup tinggi. Bahan pangan lokal, seperti singkong dan umbi jalar, banyak ditemukan di pasar tradisional dan hanya perlu beberapa proses pengolahan agar dapat diubah menjadi bentuk tepung. Keberadaan bahan baku yang cukup melimpah ini dapat membantu terciptanya berbagai macam produk olahan. Penggunaan teknologi pengolahan yang tepat dapat menghasilkan produk olahan yang tidak kalah bersaing dengan produk olahan lainnya yang hanya mengandalkan tepung terigu saja.

Pelaksanaan kegiatan ini dilakukan dengan cara memberikan penjelasan kepada mitra mengenai kegiatan yang akan dilakukan. Tim pengabdian menyampaikan beberapa poin yang terkait dengan kegiatan PKM ini. Penjelasan mengenai pentingnya diversifikasi produk olahan pangan lokal, manajemen produksi dan pendaftaran PIRT. Selain itu, koordinasi dengan mitra juga dilakukan dengan tujuan untuk menyusun jadwal kegiatan yang akan dilakukan di kemudian hari.

Sosialisasi kegiatan PKM yang dilakukan berjalan dengan lancar dan program ini mendapatkan sambutan dari pihak mitra yang cukup hangat. Antusiasme mitra dalam menyambut kegiatan yang akan dilakukan cukup besar sehingga penyusunan jadwal kegiatan dapat segera dilakukan saat itu juga. Tim pengabdian melakukan koordinasi jadwal kegiatan pada kedua mitra dengan tujuan agar tidak terjadi bentrok dengan 
kegiatan lainnya di masing-masing tempat.

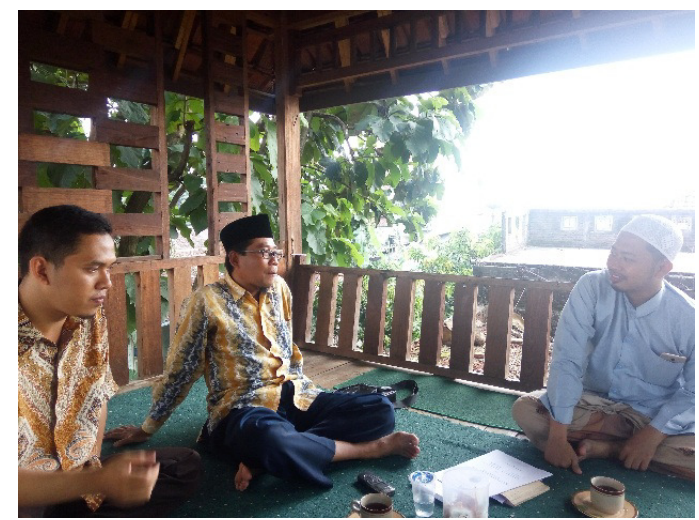

Gambar 1. Rapat koordinasi dengan mitra

Kegiatan pelatihan telah dilaksanakan dengan mengambil tempat di Laboratorium Rekayasa Proses Pengolahan Pangan Universitas PGRI Semarang. Pada kegiatan ini dipaparkan terlebih dahulu mengenai pentingnya pemanfaatan bahan baku lokal (jenis umbi-umbian) dalam pembuatan produk olahan pangan, terutama roti dan kue kering. Penjelasan ini perlu diberikan karena substistusi tepung terigu dengan sebagian tepung umbi lokal dalam pembuatan roti dan kue ini akan mengakibatkan beberapa karakteristik produk mengalamai perubahan, seperti rasio pengembangan adonan roti dan tingkat kerenyahan kue kering.

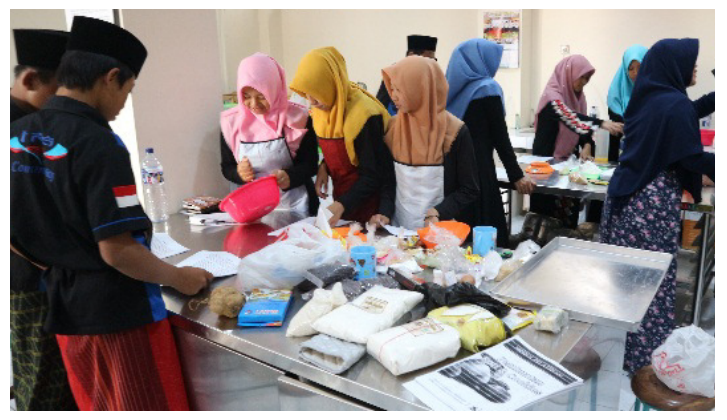

Gambar 2. Kegiatan pelatihan dasar pembuatan roti dan kue kering dari tepung umbi lokal di Laboratorium Rekayasa Proses Pengolahan Pangan UPGRIS
Penerapan teknologi pengolahan yang tepat akan membantu peserta dalam menentukan proporsi campuran yang sesuai agar produk tetap memiliki nilai jual yang cukup tinggi. Para peserta tetap antusias dalam membuat roti dan cookies ini meskipun bahan yang digunakan dari tepung singkong dan umbi jalar.

Kegiatan pengabdian selanjutnya bertempat di Pondok Pesantren Sultan Fatah Semarang, dan diikuti oleh sekitar 39 orang. Kegiatan ini berisi penyampaian beberapa materi tentang motivasi berwirausaha dan pengurusan PIRT. Materi disampaikan oleh tim pengabdian sesuai dengan bidang keahlian masing-masing personal.

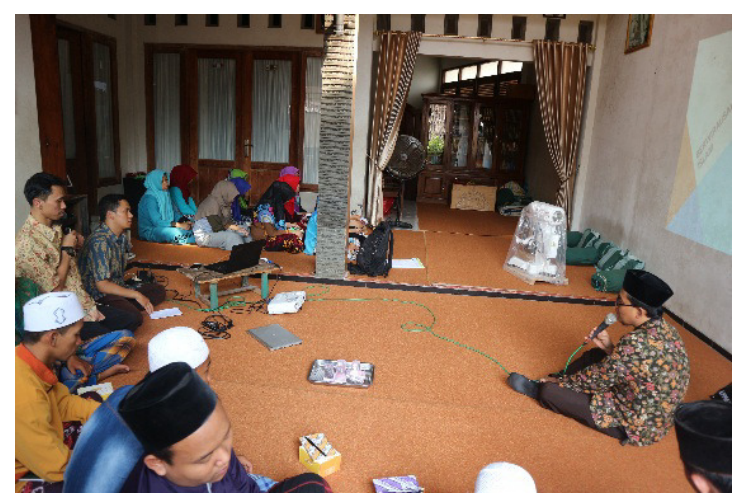

Gambar 3. Kegiatan penyuluhan pengurusan PIRT dan motivasi berwirausaha di Pondok Pesantren Sultan Fatah Semarang

Pemberian materi tentang motivasi berwirausaha, terutama dari sudut pandang agama, sangat perlu diberikan kepada para peserta kegiatan. Hal ini dikarenakan peserta yang didominasi oleh santri putra dan putri ini diharapkan memiliki keterampilan khusus setelah lulus dari pondok pesantren dan mengembangkan usaha mereka sendiri. Para 
peserta mengikuti penyuluhan dengan seksama dikarenakan pemateri memasukkan beberapa landasan hukum dari segi agama, sehingga selaras dengan ilmu yang mereka dapat di pondok pesantren.

\section{KESIMPULAN}

Hasil pelaksanaan kegiatan menunjukkan bahwa peserta telah memiliki kemampuan mengenai proses pembuatan roti. Penggunaan bahan baku tepung lokal dalam formula pembuatan produk roti memang belum menghasilkan karakteristik yang sama persis dengan produk yang dibuat dari tepung terigu.

\section{SARAN \\ Diharapkan adanya tindak lanjut pendampingan pemasaran produk yang dihasilkan mitra.}

\section{UCAPAN TERIMAKASIH}

Ucapan terimakasih penulis sampaikan kepada DRPM Kemenristekdikti atas pendanaan pada kegiatan pengabdian masyarakat tahun anggaran 2018.

\section{REFERENSI}

Anonim, 2012. Buku Kecamatan Ngaliyan dalam Angka 2012. http://bappeda.semarangkota.go.id/kategor i/1/buku-kec-ngaliyan-dlm-angka-2012.

Diakses pada 16 Juli 2017

Elizabeth R. 2011. Strategi Pencapaian Diversifikasi dan Kemandirian Pangan: Antara Harapan dan Kenyataan. Iptek Tanaman Pangan Vol. 6 (2): 230-242

Fitriani, Sarono, Widodo Yatim R. 2011. Tingkat Adopsi terhadap Diversifikasi Pangan Berbasis Jagung pada Organisasi Kelompok Masyarakat di Propinsi Lampung. Volume 24 (1): 68-73

Lastinawati E. 2010. Diversifikasi Pangan dalam Mencapai Ketahanan Pangan. AgronobiS, Vol. 2 (4): 11 - 19

Suarni. 2013. Pengembangan Pangan Tradisional Berbasis Jagung Mendukung Diversifikasi Pangan. Iptek Tanaman Pangan Vol. 8 (1): 39-47

Sukesi K., Shinta A. 2011. Diversifikasi Pangan Sebagai Salah Satu Strategi Peningkatan Gizi Berkualitas Di Kota Probolinggo (Studi Kasus Di Kecamatan Kanigaran). SEPA : Vol. 7 (2): $85-90$ 